\title{
STRUKTUR MODAL PENDEKATAN DINAMIS PERUSAHAAN OTOMOTIF DAN KOMPENENNYA SAAT KRISIS GLOBAL 2008
}

\author{
Syanti Dewi dan Ishak Ramli \\ Fakultas Ekonomi Universitas Tarumanagara \\ syantid@fe.untar.ac.id; widyasari@fe.untar.ac.id; Ishakr@fe.untar.ac.id
}

\begin{abstract}
The increase in business during the global crisis to the challenge of funding and capital structure dynamic analysis approach is suitable for the observation of the capital structure. This study is intended to demonstrate the influence of profitability, firm size, cost of equity, debt cost, and firm value volatility, leverage and speed adjustment sertaoptimal the capital structure. By using the auto company's financial statements and its components in a data 2008-2012 profitability, firm size, cost of equity, debt cost, danfirm value volatility analyzed using multiple regression analysis to examine the effect on the capital structure and leverage optimal data and speed adjustmentdianalisis method Generalized Moment Method (GMM) to examine the achievement of optimal capital structure and speed of achievement of optimal capital structure. The results found that the only significant profitability and firm size negatively affects the capital structure, the cost is being equity, debt cost, and firm value volatilitytidak significantly affect their capital structure. The automotive industry and its components was successfully adjust its capital structure to an optimal position, but the adjustment is slow. In a global crisis of capital structure adjustment to the optimal capital structure is progressing slowly in view of the difficulty of finding external funding sources.
\end{abstract}

Keywords: optimal capital structure, speed of adjustment, cost of capital, firm size

\begin{abstract}
Abstrak: Peningkatan bisnis pada saat krisis global menjadi tantangan pendanaan, dan analisis pendekatan struktur modal dinamis cocok digunakan untuk pengamatan struktur modal. Penelitian ini dimaksudkan untuk membuktikan pengaruh faktor profitability, firm size, equity cost, debt cost, dan firm value volatility, sertaoptimal leverage dan speed adjustment terhadap struktur modal. Dengan menggunakan laporan keuangan perusahaan otomotif dan komponennya tahun 2008-2012 data profitability, firm size, equity cost, debt cost, danfirm value volatility dianalisis dengan regresi berganda untuk menguji pengaruhnya terhadap struktur modal, dan data optimal leverage dan speed adjustmentdianalisis dengan metode Generalized Moment Method (GMM) untuk menguji pencapaian struktur modal optimal dan kecepatan pencapaian struktur modal optimalnya. Hasilnya ditemukan bahwa hanya profitabilitas dan firm size signifikan negatif mempengaruhi struktur modalnya sedang equity cost, debt cost, dan firm value volatilitytidak signifikan mempengaruhi struktur modalnya. Industri otomotif dan komponennya ternyata berhasil menyesuaikan struktur modal nya kepada posisi optimal namun penyesuaiannya berjalan lamban. Dalam krisis global penyesuaian struktur modal kepada struktur modal optimalnya berjalan lamban mengingat sulitnya mendapatkan sumber dana eksternal.
\end{abstract}

Kata kunci: struktur modal optimal, speed of adjustment, cost of capital, firm size 


\section{PENDAHULUAN}

Krisis global tahun 2008 memberikan dampak terhadap perekonomian dunia termasukIndonesia. Penjualan di beberapa industri menurun, namun penjualan industri otomotif dan komponennya di Indonesia mengalami peningkatan. Tabel 1.1 penjualan bersih atau pendapatan industri otomotif dan komponennya yang terdaftar di Bursa Efek Indonesia selama 5 tahun terakhir rata-rata terjadi peningkatan :

Tabel 1. Penjualan Industri Sektor Otomotif dan Komponennya di Indonesia (dalam jutaan rupiah)

\begin{tabular}{|l|r|r|r|r|r|r|}
\hline Perusahaan & \multicolumn{1}{c|}{2007} & \multicolumn{1}{c|}{2008} & \multicolumn{1}{c|}{2009} & \multicolumn{1}{c|}{2010} & \multicolumn{1}{c|}{2011} & \multicolumn{1}{c|}{2012} \\
\hline ASII & 70.183 .000 & 97.064 .000 & 98.526 .000 & 129.991 .000 & 162.564 .000 & 188.053 .000 \\
\hline AUTO & 4.184 .279 & 5.337 .720 & 5.265 .798 & 6.255 .109 & 7.363 .659 & 8.277 .485 \\
\hline BRAM & 1.547 .112 & 1.637 .886 & 1.500 .639 & 1.805 .360 & 1.900 .212 & 1.250 .992 \\
\hline GDYR & 1.088 .862 & 1.244 .519 & 1.292 .819 & 1.736 .088 & 1.879 .889 & 1.483 .897 \\
\hline GJTL & 6.659 .854 & 7.963 .473 & 7.936 .432 & 9.853 .904 & 11.841 .396 & 9.381 .418 \\
\hline IMAS & 5.084 .057 & 8.197 .135 & 6.939 .570 & 10.935 .335 & 15.776 .580 & 14.597 .467 \\
\hline INDS & 412.534 & 963.198 & 720.229 & 1.027 .120 & 1.234 .986 & 1.105 .771 \\
\hline LPIN & 34.229 & 59.249 & 58.088 & 59.519 & 62.958 & 47.112 \\
\hline MASA & 898.335 & 1.333 .604 & 1.691 .475 & 2.006 .840 & 2.861 .930 & 2.308 .032 \\
\hline NIPS & 283.460 & 480.458 & 279.929 & 400.895 & 579.224 & 485.515 \\
\hline PRAS & 528.934 & 410.673 & 161.201 & 74.974 & 330.447 & 242.278 \\
\hline SMSM & 1.064 .055 & 1.353 .586 & 1.374 .652 & 1.561 .787 & 1.807 .891 & 465.691 \\
\hline TOTAL & 91.968 .711 & 126.045 .501 & 125.746 .832 & 165.707 .931 & 208.203 .172 & 227.698 .658 \\
\hline
\end{tabular}

Sumber : Ringkasan kinerja perusahaan tercatat (www.idx.co.id)

Peningkatan terjadi pada tahun 2008 kemudian menurun pada tahun 2009 namun kembali meningkat pada tahun 2010 sampai 2012. Pertumbuhan industri sektor otomotif dan komponennya menunjukkan fenomena yang menarik pada saat krisis. Pertumbuhan penjualan dalam situasi krisis global mengundang pertanyaan bagaimana perusahaan mendanai investasi modal kerja dan modal tetap untuk operasi perusahaan tersebut.

Krisis global yang terjadi memungkinkan perusahaan yang ada di Indonesia memilki risiko kebangkrutan yang tinggi. Oleh karenanya perusahaan seharusnya akan lebih berhati-hati dalam membuat keputusan pendanaan perusahaan. Grafik 1.2 memperlihatkan fenomena yang menarik pula yaitu bahwa tingkat debt to equity ratio (DER) perusahaan industri dalam sektor otomotif mengalami penurunan tiap tahun (rata-rata DER perusahaan mengalami penurunan mulai dari tahun 2008 sampai tahun 2012). Tingkat debt-to-equity ratio yang dimiliki setiap perusahaan berubah-ubah setiap dari waktu kewaktu.

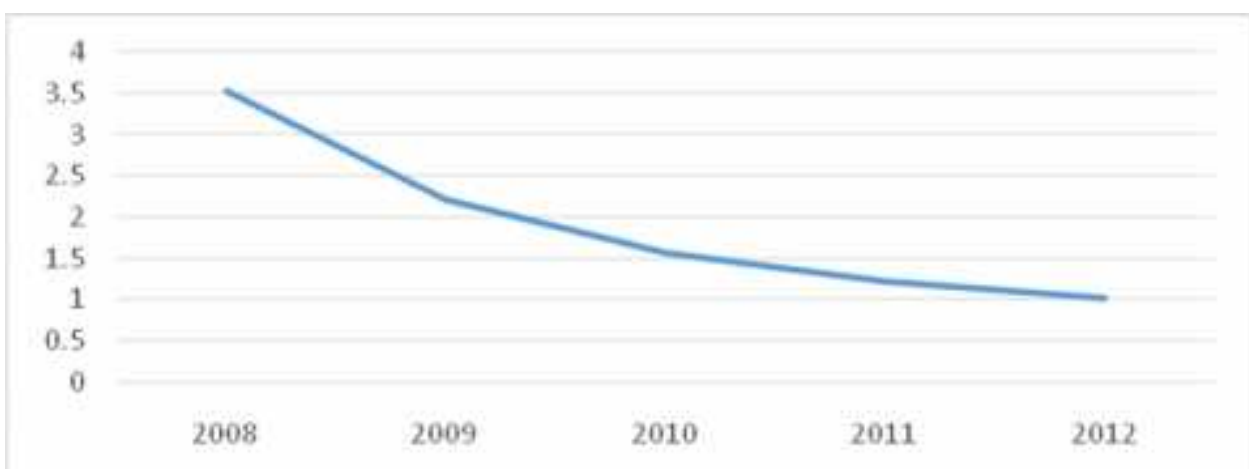

Grafik 1. Debt-to-Equity Ratio (DER) Perusahaan Industri Sektor Otomotif dan Komponennya yang tercatat di Bursa Efek Indonesia (2008-2012)

Sumber : Bursa Efek Indonesia (www.idx.co.id) 
Sumber pendanaan utang menurun dalam struktur modal (capital structure) industri otomotif dan komponennya.Sumber dana yang dibutuhkan perusahaan guna menunjang pertumbuhan industri dapat diperoleh dari sumber internal dan eksternal perusahaan. Sumber dana internal berasal dari dalam perusahaan yaitu dari hasil kegiatan operasi perusahaan, laba yang ditahan yaitu bagian laba yang tidak dibagikan dalam bentuk dividen kas. Sumber dana eksternal berasal dari luar perusahaan yaitu berasal dari utang (pinjaman) dan modal sendiri (saham). Menurut Sunder dan Myers (1994), perusahaan lebih baik menggunakan pendanaan yang berasal dari dalam perusahaan (sumber internal) dibandingkan dengan pendanaan yang berasal dari luar perusahaan (sumber eksternal).

Mengingat pencapaian struktur modal optimal membutuhkan waktu maka perubahan struktur modal terus terjadi dari waktu ke waktu sesuai dengan keadaan kinerja perusahaan dan berapa cepat perubahan keadaan operasional perusahaan tersebut menyesuaikan struktur modalnya. Struktur modal yang bergerak menyesuaikan kepada struktur modal optimalnya disebut sebagai struktur modal yang dinamis (Manurung, 2012).

Menurut Manurung (2012) teori struktur kapital dinamis ini berangkat dari kelemahan model statis yaitu bahwa model statis melupakan adanya restrukturisasi optimal struktur kapital untuk merespons adanya fluktuasi dalam nilai aset sepanjang waktu. Artinya, perusahaan selalu melakukan penyesuaian besar utangnya dalam rangka merespon perubahan aset perusahaan.

Menurut Graham dan Harvey (1999), dalam Ruslim (2010) karakteristik perusahaan menjadi faktor penyebab yang dapat menentukan struktur modal bersifat dinamis. Perusahaan yang cenderung menggunakan utang dalam pendanaan mempunyai target rasio utang optimal. Dalam kenyataannya, apabila perusahaan banyak menggunakan utang dalam pendanaannya, maka perusahaan berisiko mengalami financial distress.

Menurut literatur faktor-faktor penentu yang dapat mempengaruhi struktur modal perusahaan akan menjadi suatu dasar pertimbangan perusahaan ketika menentukan komposisi sturktur modal nya. Profitabilitas dapat digunakan sebagai proxy untuk teori pecking-order karena memiliki kekuatan penjelas yang signifikan. SelanjutnyaGorvenance structure secara signifikan mempengaruhi speed of adjustment dalam menyesuaikan rasio tingkat utang atau leverage yang optimal. Selain itu Equity cost dan debt cost signifikan mempengaruhi struktur modal. Sementara Volatility firm value, profitability, firm size, tangible asset, dan market to book ratio signifikan negatif mempengaruhicapital structure(Nishioka dan Baba, 2004).

Karakteristik perusahaan (profitability, growth opportunities, long term debt, dan retained earnings) juga signifikan mempengaruhi struktur modal (dinamis) dalam jangka pendek kecuali size dan operating risk tidak signifikan mempengaruhi struktur modal (dinamis) dalam jangka pendek (Ruslim, 2010).Operating risk, size, tangibility mempunyai hubungan yang positif terhadap leverage, sedangkan growth,profitability memiliki hubungan yang negatif terhadap leverage dan pencapaian target leverage optimal (Gaud, dkk., 2003). Faktor-faktor lain yang mempengaruhi struktur modal perusahaan adalah stabilitas penjualan, struktur aktiva, leverage operasi, tingkat pertumbuhan, profitabilitas, pajak, pengendalian, sikap manajemen, sikap pemberi pinjaman, kondisi pasar, kondisi internal pasar, dan fleksibilitas keuangan ( Brigham dan Houston, 2001). Sementara temuan Seftianne dan Handayani (2011) size dan growth opportunity mempengaruhi capital structure sedangkan liquidity, profitability, risiko bisnis, kepemilikan managerial, dan struktur aktiva tidak mempengaruhi capital structure.Temuan Fan, Titman dan Twite (2011)tangible assets dan firm sizememiliki pengaruh yang positif terhadap leveragesedangkan profitabilitydan market to book ratiomemiliki pengaruh negatif terhadapleverage. Profitability, firm sizedan market to book ratioberpengaruh positif terhadapdebt to maturity.

Titman dan Wessels (1988) berkenaan denganThe Determinants of Capital Structure Choice menunjukkan bahwanon debt tax shield, collateral value, volatility dan future growth tidak bepengaruh terhadap capital structure sedangkan uniquenes, size, volatility, and profitability memiliki pengaruh negatif terhadap capital structure.Sementara temuan Margaretha dan Ramadhan (2010) ukuran perusahaan, tangibility,profitability, liquidity, growth, dan umur 
perusahaan mempengaruhicapital structuretetapinon-debt tax shielddan investasi tidak mempengaruhi capital structuresecara signifikan. Bevan dan Danbolt (2000) menemukan profitability signifikan negatif mempengaruhi gearing. Tangibilitydan sizesignifikan positif mempengaruhi utang jangka panjang dan signifikan negatif terhadap utang jangka pendek. Growth opportunitiespositif signifikan mempengaruhi utang jangka pendek.

Penelitian tentang penurunan struktur modal pada industri otomotif dan komponennya pada situasi krisis global menjadi menarik untuk diteliti. Pendekatan dinamis terhadap struktur modal industri tersebut lebih tepat dalam menjelaskan fenomena tersebut pada situasi krisis global pada tahun 2008, mengingat struktur modal perusahaan saat krisis global perlu penyesuaian yang harus dilakukan dari waktu kewaktu. Situasi krisis global yang penuh risiko financial distress menjadikan penggunaan dana dari utang sulit diperoleh, sementara penggunaan ekuitas lewat right issue menjadi tantangan yang harus disikapi perusahaan-perusahaan terutama yang membutuhkan dana karena pertumbuhan industri serta faktor-faktor apa saja yang menjadi penentu struktur modal dalam situasi krisis global.

Mengingat struktur modal penting dalam mengatasiasimetri infomasi melalui pemberian signal kepada pengguna laporan keuangan guna menggambarkan baik situasi hasil operasi masa datang maupun risiko perusahaan mengalami financial distress, maka urgensi penelitian ini adalah dengan pendekatan dinamis saat krisis global tahun 2008dalam menemukan faktor-faktor penentu struktur modal serta seberapa cepat perubahan struktur modal nya menuju struktur modal optimal.

\section{KAJIAN TEORI}

Konsep struktur modal (capital structure)menggambarkan pengabungan atau bobot relatif dari utang jangka panjang dan ekuitas (modal sendiri) sebagai pembiayaan perusahaan permanen untuk kegiatan operasional dan pertumbuhan perusahaan. Pendekatan statis struktur modal berbeda dengan pendekatan dinamis karena rasio utang yang aktual dalam pendekatan statis rasio utang yang terobservasi di perusahaan dianggap sebagai rasio utang optimal sedangkan pada pendekatan dinamis struktur modal aktual tidak dapat dilihat sebagai rasio utang yang optimal. Sementara Optimal Leverage atau Tingkat Utang Optimalmerupakan tingkat utang yang memberikan benefit dan cost penggunakan utang yang menghasilkan hasil benefit atau cost yang seimbang, yaitu merupakan fungsi atau model dari sejumlah variabel determinan atau faktor-faktor penentu tingkat utang optimal (baik firm specific effect dan time specific effect) yang memberikan keuntungan dan biaya dari penggunaan utang yang seimbang kepada perusahaan(Manansang, 2012; Nishioka dan Baba, 2004;Korteweg dan Strebulaev, 2012)

Profitability mempengaruhi capital structure. Profitability merupakan sekelompok rasio yang memperlihatkan pengaruh gabungan atau hubungan kemampuan perusahaan untuk menghasilkan pendapatan atau laba dan biaya-biaya dengan menggunakan aset, baik aset lancar maupun aset tetap (manajemen aktiva) serta mengelola penjualan, maupun modal sendiri dalam aktivitas produksi perusahaan ( Brigham dan Houston, 2001:89 ;Gitman dan Zutter, 2012:601)

Menurut teori static trade-off struktur modal yang optimal dicapai pada saat keuntungan penggunaan utang tersebut seimbang dengan biaya leverage seperti biaya kebangkrutan (financial distress cost). Keuntungan penggunaan utang adalah bahwa biaya modal lebih kecil karena ada penghematan pajak atas bunga yang dibayar. Oleh karena itu profitabilitas masa lalu dan jumlah laba yang ditahan menjadi hal penting dalam menentukan struktur pendanaan. Dalam rangka menghindari financial distress perusahaan yang mempunyai laba usaha yang lebih besar akan mempunyai akses yang lebih besar dalam pendanaan internalnya dan cenderung menggunakan sedikit utang dalam struktur pendanaannya. Pengaruh Profitability negatif siginifikan terhadap capital structure (Titman dan Wessels, 1988). Mengingat pendanaan internal sangat tergantung dari laba usaha (EBIT) yang dihasilkan perusahaan, maka profitability dengan pengukuran return on asset tidak mempengaruhi capital structure secara signifikan. Faktor yang mempengaruhi 
capital structure secara signifikan adalah rasio laba ditahan terhadap total aset dan rasio EBIT terhadap total aset (Manurung, 2011). Profitability dariperiode sebelumnya merupakan faktor penting dalam menentukan struktur modal. Dengan laba ditahan yang besar perusahaan akan lebih senang menggunakan laba ditahan sebelum menggunakan utang. Hal ini sesuai dengan teori pecking order bahwa pendanaan investasi bersumber dari internal perusahaan diutamakan, kemudian urutan berikutnya bila pendanaan dari internal tidak mencukupi digunakan pendanaan utang dan terakhir bila dana internal dan utang tidak mencukupi, digunakan pendanaan saham. (Sartono, 2001)

Firm size mempengaruhi capital structure. Ukuran perusahaan (firm size) menggambarkan besar kecilnya skala perusahaan berkaitan dengan prospek perusahaan dimasa depan dengan melihat total aset dan tingkat penjualan yang dimiliki perusahaan yang mampu memberikan signal kepada pemegang saham bahwa dengan total aset atau tingkat penjualan yang besar akan memiliki prospek yang baik. Perusahaan yang besar akan lebih mudah terdiversifikasi dan memiliki kemungkinan yang rendah mengalami kesulitan keuangan (Rajan dan Zingales,1995). Semakin besar ukuran perusahaan maka semakin besar kemungkinan mendanai pemenuhan kebutuhannya dengan utang. Firm size (ukuran perusahaan) memiliki pengaruh positif terhadap leverage atau capital structure( Gaud, dkk., 2003). Perusahaan yang besar, kecil kemungkinan mengalami kebangkrutan sehingga firm size akan cenderung menggunakan utang, karena biaya modal nya yang lebih kecil karena adanya penghematan pajak atas bunga yang dibayar. Pada kenyataannya bahwa semakin besar suatu perusahaan maka kecenderungan penggunaan dana eksternal juga akan semakin besar. Hal ini disebabkan karena perusahaan yang besar memiliki kebutuhan dana yang besar dan salah satu pemenuhan dana yang tersedia menggunakan penggunaan dana eksternal ( Titman dan Wessels, 1998).

Pada perusahaan unlisted di Macedonia penggunaan utang lebih banyak dibandingkan dengan perusahaan listed, karena perusahaan belum mempunyai akses terhadap pendanaan ekuitas di pasar modal. Firm size tidak memiliki pengaruh terhadap keputusan capital structure pada perusahaan listed maupun unlisted di Macedonia, karena baik perusahaan kecil maupun besar yang listed dan unlisted lebih suka menggunakan dana internal dari hasil usaha nya (Deari dan Deari, 2009) dalam Manurung, 2011).

Equity cost mempengaruhi capital structure. Equity cost merupakan biaya yang timbul dari penggunaan dana yang berasal dari investor (berupa ekuitas) yaitu berupa pengembalian (return) yang diharapkan atau diinginkan pemegang saham, menggambarkan suatu hubungan antara tingkat risiko dan tingkat pengembalian yang diharapkan.

Equity cost mencerminkan tingkat hasil (return) yang dituntut atau diinginkan pemegang saham. Pencapaian struktur modal optimal perusahaan terjadi saat value berada pada nilai tertingginya atau maksimum dengan menanggung biaya modal (biaya ekuitas dan biaya utang) tertentu yang seimbang sehingga hal ini dapat menentukan keputusan capital structureyang tepat serta memiliki pengaruh negatif terhadap capital structure ( Prihadi, 2012:269).Equity cost memiliki pengaruh signifikan positif karena semakin tinggi equity cost, semakin tinggi pula rasio leverage yang optimal. Hasil ini menunjukkan kebenaran secara empiris sebagai kerangka dasar teori trade-off (Nishioka dan Baba, 2004).

Debt cost mempengaruhi capital structure. Debt cost merupakan biaya yang timbul (bunga) akibat perusahaan menggunakan sumber dana dari kreditor dan atau juga merupakan tingkat pengembalian bank dari pinjaman baru yang menggambarkan besarnya 
tingkat bunga yang berlaku sekarang, tingkat risiko kebangkrutan, dan tingkat pajak yang terkait dengan utang yang dibayarkan atas pinjamanDebt cost (biaya utang) timbul akibat perusahaan menggunakan sumber dana dari kreditor. Dalam mencapai struktur modal optimal perusahaan memiliki nilai tertingginya serta menanggung biaya modal (baik biaya ekuitas dan biaya utang) tertentu yang memberikan manfaat nilai tertinggi tersebut, sehingga hal ini dapat digunkan dalam menentukan keputusan capital structure ( Prihadi, 2012:291).Debt cost memiliki pengaruh negatif terhadap capital structure karena semakin tinggi biaya utang, semakin rendah rasio leverage yang optimal. Hasil ini menunjukkan kebenaran secara empiris dari teori trade-off sebagai kerangka dasar (Nishioka dan Baba, 2004).

Volatility firm value mempengaruhi capital structure. Volatilitas(volatility) harga saham merupakan ukuran ketidakpastian pergerakan harga saham dimasa yang akan datang. Makin meningkatnya volatilitas berarti kemungkinan naik atau turunnya harga saham juga semakin besar. Volatilitas(volatility) adalah deviasi standar dari continuosly compound return pada saham. Dalam perhitunganvolatilitas(volatility) digunakan data historis dari harga saham padainterval waktu tertentu misalnya harian, mingguan ataubulanan.Volatility (volatilitas) firm value merupakan ukuran ketidakpastian pergerakan harga saham dimasa datang atau tingkat risiko akibat return saham harian yang akan dihadapi perusahaan. Banyak peneliti telah menyarankan bahwa tingkat utang yang optimal suatu perusahaan merupakan fungsi penurunan volatilitas produktif. Volatility firm valuememberikan pengaruh negatif kepada capital structure, hal inimerupakan kebenaran empiris sebagai kerangka dasar teori trade-off, mengingat banyak hasil pengujian empiris dibeberapa Negara menunjukkan volatilitas value of the firm berbanding terbalik dengan besaran capital structure (Nishioka dan Baba, 2004; dan Titman dan Wessels, 1988).Volatilitas yang tinggi berada dalam probabilitas kegagalan yang tinggi juga, sehingga tanda negatif diharapkan terjadi dari hasil studi empiris ( Merton, 1974). Makin besar volatilitas nilai perusahaan makin besar atau makin berisiko perusahaan mengalami financial distress bila menggunakan utang sebagai pendanaan pertumbuhan investasinya.

Optimal leverage mempengaruhi capital structure. Tingkat utang optimal merupakan fungsi dari sejumlah variabel firm specific effect dan time specific effect. Karena faktorfaktor penentu tingkat utang optimal itu dapat berubah sepanjang waktu, maka tingkat utang optimal juga akan bervariasi sepanjang waktu sehingga membuat capital structure bersifat dinamis (Manansang, 2012). Optimal leverage diperbolehkan untuk bervariasi di seluruh perusahaan dari waktu ke waktu karena faktor-faktor yang menentukan leverage yang optimal suatu perusahaan dapat berubah dari waktu ke waktu, ada kemungkinan bahwa rasio utang yang optimal dapat bergerak dari waktu ke waktu untuk perusahaan yang sama. Hal ini menangkap sifat dinamis dari masalah struktur modal. Pencapain tingkat utang optimal tergantung darispeed of adjustment (Hesmati, 2001).

Speed of adjustment mempengaruhi capital structure. Speed of adjustment merupakan kecepatan penyesuaian terhadap struktur modal yang optimal, hal ini ditentukan oleh biaya berpindah dari satu struktur modal kepada struktur modal yanglain. Speed adjustmentmerupakan suatu fungsi dari sejumlah variabel yang mempengaruhi biaya tingkat utang yang ditentukan oleh jarak antara tingkat utang aktual dengan tingkat utang optimal 
Speed of adjustment sama seperti leverage optimal, bisa berubah dari waktu ke waktu, kecepatan penyesuaian juga diperbolehkan untuk bervariasi di seluruh perusahaan dari waktu ke waktu sehingga capital structure yang terjadi adalah dinamis yaitu terus bergerak dalam rangka mencapai tingkat optimal nya disesuaikan dengan situasi operasi dan keuangan perusahaan. Speed of adjustmentyang lamban akan lamban mencapai capital structure yang optimal, sebaliknya speed of adjustment yang cepat akan juga cepat mengubah capital structure mencapai tingkat optimal nya.Speed of adjustment atau kecepatan penyesuaian terhadap struktur modal yang optimal ditentukan oleh biaya perpindahan dari satu struktur modal ke struktur modal yang lain. Maka dengan adanya biaya berpindah dari suatu struktur modal satu ke struktur modal yang lain menunjukkan struktur modal yang dinamis. Pencapain tingkat utang optimal dan speed of adjustmentyang sangat lamban juga akan lambat mencapai struktur modal optimal nya (Loof, 2003).

Berdasarkan landasan teori dan kerangka pemikiran, maka hipotesis yang dapat dibentuk guna menduga sementar saat krisis global adalah sebagai berikut :

Hipotesis 1 : Profitability (return on asset), firm size, equity cost, debt cost, volatility secara simultan atau bersama-sama mempengaruhi structure pada tahun 2008-2012

Hipotesis 2 : Profitability (return on asset) mempengaruhi capital structure pada tahun 2008-2012

Hipotesis 3 : Firm sizemempengaruhi capital structure pada tahun 2008-2012

Hipotesis 4 : Equity cost mempengaruhi capital structure pada tahun 2008-

\section{2}

Hipotesis 5 : Debt cost mempengaruhi capital structure pada tahun 2008-2012

Hipotesis 6 : Volatilyfirm value mempengaruhi capital structure pada tahun 2008-2012

Hipotesis 7 : Tingkat utang optimal atau optimal leverage mempengaruhi capital structure pada tahun 2008-2012

Hipotesis 8 : Speed of adjustment mempengaruhi capital structure pada tahun 2008-2012

\section{METODE}

Data. Data sekunder yang digunakan dalam penelitian ini berupa data laporan keuangan perusahaan industri otomotif dan komponen pada periode 2008-2012 yang diperoleh dari situs resmi Bursa Efek Indonesia (www.idx.co.id). Data listing perusahaan diperoleh dari situs resmi www.sahamok.com.

Data yang digunakan dalam penelitian ini adalah data panel (gabungan data cross-section dan time-series).

Teknik analisis data menggunakan analisis regresi berganda (pendekatan dinamis) dan analisis metode Generalized Moment Method (GMM). Sebelum melakukan analisis regresi berganda dan analisis metode Generalized Moment Method (GMM) dengan data panel dilakukan uji Hausman.

\section{HASIL DAN PEMBAHASAN}

Berdasarkan pada Tabel 4.2 nilai Hausman-Test sebesar 0.0428. nilai Hausman-Test < signifikansi maka dapat disimpulkan Ho ditolak dengan kata lain Ha diterima atau metode fixed effect lebih baik untuk mengestimasi data panel pada tahun 2008-2012. 
Tabel 2. Hausman-Test Regresi pada tahun 2008-2012

\begin{tabular}{lrrr}
\hline \hline Test Summary & $\begin{array}{r}\text { Chi-Sq. } \\
\text { Statistic }\end{array}$ & Chi-Sq. d.f. & Prob. \\
\hline \hline Cross-section random & 14.130914 & 5 & 0.0148 \\
\hline \hline
\end{tabular}

Sumber : Hasil pengelolahan data menggunakan Eviews 6.

Tabel 3. Hasil Analisis Regresi Berganda Pada tahun 2008-2012

\begin{tabular}{|c|c|c|c|c|}
\hline Variable & Coefficient & Std. Error & t-Statistic & Prob. \\
\hline $\mathrm{C}$ & 22.97995 & 7.798408 & 2.946749 & 0.0052 \\
\hline ROA? & -12.14578 & 3.247394 & -3.740162 & 0.0005 \\
\hline SIZE? & -0.749250 & 0.270180 & -2.773148 & 0.0082 \\
\hline EC? & 0.067217 & 0.220255 & 0.305177 & 0.7617 \\
\hline DC? & -0.970080 & 0.578114 & -1.678007 & 0.1006 \\
\hline VOLA? & 0.358742 & 3.061565 & 0.117176 & 0.9073 \\
\hline \multicolumn{5}{|c|}{ Effects Specification } \\
\hline \multicolumn{5}{|c|}{ Cross-section fixed (dummy variables) } \\
\hline R-squared & 0.665959 & \multicolumn{2}{|c|}{ Mean dependent var } & 0.658921 \\
\hline Adjusted R-squared & 0.541664 & \multicolumn{2}{|c|}{ S.D. dependent var } & 1.033131 \\
\hline S.E. of regression & 0.699435 & \multicolumn{2}{|c|}{ Akaike info criterion } & 2.356434 \\
\hline Sum squared resid & 21.03600 & \multicolumn{2}{|c|}{ Schwarz criterion } & 2.949832 \\
\hline Log likelihood & -53.69303 & \multicolumn{2}{|c|}{ Hannan-Quinn criter. } & 2.588545 \\
\hline F-statistic & 5.357909 & \multirow{2}{*}{\multicolumn{2}{|c|}{ Durbin-Watson stat }} & 1.454654 \\
\hline Prob(F-statistic) & 0.000005 & & & \\
\hline
\end{tabular}

Sumber : Hasil Pengelolahan Data menggunakan Eviews 6.

Hasil regresi data panel:

$\mathrm{DER}=22.97995-12.14578 \mathrm{ROA}-0.749250 \mathrm{FZ}+0.067217 \mathrm{EC}$

$0.970080 \mathrm{DC}+0.358742$ VOLA +7.798408

Keterangan $:$ DER $=$ Debt to total equity pada tahun 2008-2012; AG $=$ Asset growth pada tahun 2008-2012; ROA = Return on asset pada tahun 2008-2012; FZ= Firm Size pada tahun 2008-2012; EC = Equity cost pada tahun 2008-2012; DC = Debt cost pada tahun 2008-2012; VOLA = Volatility firm value pada tahun 2008-2012

Uji hipotesis 1 dilakukan dengan Uji-F. Uji-F (uji simultan) untuk menguji pengaruh profitability (return on asset), firm size (ln asset), equity cost (CAPM), debt cost (interest expenses after tax to total debt) dan volatility firm value (standar deviation of daily stock return) secara bersama-sama terhadap capital structure pada tahun 2008-2012. Nilai sig $=0.000005$ (Tabel 3)

Nilai tingkat nyata $(\alpha)=0.05$. Nilai sig < nilai tingkat nyata $(\alpha)=0.000005<0.05$

Ho ditolak berarti Probability (return on asset), firm size (in aset), equity cost (CAPM), debt cost (interest expenses after tax to total debt) dan volatility firm value (standar deviation of daily 
stock return) secara bersama-sama signifikan mempengaruhi capital structure pada tahun 2008-2012

Uji hipotesis 2,3,4,5,6 dilakukan dengan Uji-t .Hipotesis 2 : Profitability (return on asset) mempengaruhicapital structure. Tabel 3 menunjukkan bahwa pada tahun 2008-2012, profitability signifikan mempengaruhi capital structure dengan nilai kritis 0.0005 .

Hipotesis 3 :Firm size (ln asset) mempengaruhi capital structure. Tabel 3. menunjukkan bahwa pada tahun 2008-2012, firm size signifikan mempengaruhi capital structure dengan nilai kritis 0.0082 .

Hipotesis 4 :Equity cost (CAPM) mempengaruhi capitalstructure. Tabel 3 menunjukkan bahwa pada tahun 2008-2012, equity cost tidak signifikan mempengaruhi capital structure dengan nilai kritis 0.7617 .

Hipotesis 5 :Debt cost (interest expense after tax to total debt) mempengaruhi capital structure. Tabel 3. menunjukkan bahwa pada tahun 2008-2012, debt cost tidak signifikan mempengaruhi capital structure dengan nilai kritis 0.1006 .

Hipotesis 6 : Volatility firm value (standard deviation of dailystock return) mempengaruhi capital structure. Tabel 3 menunjukkan bahwa pada tahun 2008-2012, volatility firm value tidak signifikan mempengaruhi capital structure dengan nilai kritis 0.9073 .

Ujihipotesis 7 dan 8 dilakukan dengan GMM dan analisis PAM. Metode Generalized Moment Method (GMM). Pada analisis ini merupakan tahap menguji untuk hipotesis kedelapan dan hipotesis kesembilan dengan metode Generalized Moment Method (GMM) pada Eviews 6. Tingkat utang optimal dan speed of adjustment dilakukan dengan menggunakan Partial Adjustment Model (PAM). Berikut hasil tingkat utang optimal atau optimal leverage $\left(L E V^{*} i t\right)$ setelah dimasukan ke dalam model :

Tabel 4. Hasil Tingkat Utang Optimal

\begin{tabular}{ccccc}
\hline Lev*it & ASII & AUTO & BRAM & GDYR \\
\hline 2008 & $-22,408189$ & $-22,426881$ & $-23,260749$ & $-21,748274$ \\
2009 & $-22,366086$ & $-22,794985$ & $-22,640632$ & $-23,040301$ \\
2010 & $-22,702620$ & $-23,482268$ & $-22,989610$ & $-22,603766$ \\
2011 & $-22,800839$ & $-22,963580$ & $-22,222040$ & $-22,150522$ \\
2012 & $-22,777461$ & $-22,776848$ & $-23,396703$ & $-22,946553$ \\
Lev*it & GJTL & IMAS & INDS & LPIN \\
2008 & $-19,908126$ & $-19,867304$ & $-21,549303$ & $-22,863801$ \\
2009 & $-21,900386$ & $-20,074473$ & $-22,065486$ & $-22,803966$ \\
2010 & $-21,770493$ & $-20,873629$ & $-22,527561$ & $-23,036643$ \\
2011 & $-21,667599$ & $-21,321615$ & $-22,684267$ & $-22,748699$ \\
2012 & $-22,098039$ & $-21,252703$ & $-22,682208$ & $-23,243279$ \\
Lev*it & MASA & NIPS & PRAS & SMSM \\
2008 & $-21,575706$ & $-22,267857$ & $-21,446787$ & $-22,922641$ \\
2009 & $-22,541586$ & $-22,419539$ & $-20,454640$ & $-22,440473$ \\
2010 & $-22,404883$ & $-22,972016$ & $-21,510536$ & $-22,396503$ \\
2011 & $-22,266230$ & $-23,057827$ & $-23,293963$ & $-23,063535$ \\
2012 & $-22,197679$ & $-23,346626$ & $-22,046753$ & $-23,203437$ \\
\hline
\end{tabular}

Sumber : Hasil Pengelolaan Data menggunakan Excel. 
Penyesuaian (Speed of Adjustment). Penyesuaian tingkat utang ke pencapaian tingkat optimal. Berikut hasil peregresian antara tingkat utang pada perusahaan tertentu waktu atau tahun sebelumnya dengan tingkat utang optimal pada perusahaan tertentu waktu atau tahun tertentu :

Tabel 5. Hasil Regresi LEVit-1 dengan LEV*it

\begin{tabular}{|c|c|c|c|c|}
\hline Variable & Coefficient & Std. Error & t-Statistic & Prob. \\
\hline $\mathrm{C}$ & 14.86900 & 2.525432 & 5.887707 & 0.0000 \\
\hline LEVit-1 & 0.315123 & 0.067439 & 4.672746 & 0.0000 \\
\hline LEV*it & 0.648546 & 0.111372 & 5.823259 & 0.0000 \\
\hline R-squared & 0.765879 & \multicolumn{2}{|c|}{ Mean dependent var } & 0.658921 \\
\hline Adjusted R-squared & 0.757664 & \multicolumn{2}{|c|}{ S.D. dependent var } & 1.033131 \\
\hline S.E. of regression & 0.508586 & \multicolumn{2}{|c|}{ Sum squared resid } & 14.74359 \\
\hline F-statistic & 93.23192 & \multicolumn{2}{|c|}{ Durbin-Watson stat } & 2.103497 \\
\hline Prob(F-statistic) & 0.000000 & & & \\
\hline
\end{tabular}

Sumber : Hasil Pengelolaan Data menggunakan Eviews 6.

Dari Tabel 5 dapat dilihat koefisien LEVit-1 adalah sebesar 0.315123 sebagai nilai dit untuk tingkat utang perusahaan dengan waktu atau tahun sebelumnya dan hasil koefisien LEV*it adalah sebesar 0.648546 sebagai nilai $\delta i t$ untuk tingkat utang optimal perusahaan dengan waktu atau tahun tertentu. Setelah mendapatkan nilai untuk masing-masing $\delta i t$ langkah selanjutnya adalah nilai masing-masing Sit dimasukkan ke dalam model analitik faktor speed of adjustment. Nilai masing-masing Sit didapat dari perhitungan Tabel 5. Nilai faktor dari speed of adjustment ini berubah-ubah sepanjang waktu pada perusahaan tertentu. Berikut adalah hasil tingkat utang yang melakukan penyesuaian ke tingkat utang optimal atau model analitik faktor speed of adjustment :

Tabel 6. Hasil Speed of Adjustment

\begin{tabular}{ccccc}
\hline LEVit & ASII & AUTO & BRAM & GDYR \\
\hline 2008 & $-14,243626$ & $-14,396744$ & $-14,808886$ & $-13,978599$ \\
2009 & $-14,140028$ & $-14,629844$ & $-14,589874$ & $-13,884647$ \\
2010 & $-14,419803$ & $-15,097323$ & $-14,830229$ & $-14,243561$ \\
2011 & $-14,521976$ & $-14,792445$ & $-14,297099$ & $-14,093545$ \\
2012 & $-14,443051$ & $-14,653880$ & $-15,015498$ & $-14,718291$ \\
LEVit & GJTL & IMAS & INDS & LPIN \\
2008 & $-11,572387$ & $-7,505798$ & $-12,279449$ & $-14,752445$ \\
2009 & $-12,048240$ & $-8,961150$ & $-13,163877$ & $-14,711866$ \\
2010 & $-12,912054$ & $-11,317964$ & $-14,004241$ & $-14,848985$ \\
2011 & $-13,199983$ & $-12,827760$ & $-14,250710$ & $-14,659351$ \\
2012 & $-13,625688$ & $-13,386056$ & $-14,445132$ & $-14,978729$ \\
LEVit & MASA & NIPS & PRAS & SMSM \\
2008 & $-13,815183$ & $-14,154783$ & $-13,574060$ & $-14,362547$ \\
2009 & $-12,493763$ & $-14,322138$ & $-12,772098$ & $-14,427489$ \\
2010 & $-14,349922$ & $-14,743310$ & $-11,930004$ & $-14,408067$ \\
2011 & $-14,222373$ & $-14,824208$ & $-14,142000$ & $-14,696381$ \\
2012 & $-14,204378$ & $-14,933459$ & $-13,594126$ & $-14,806941$ \\
\hline
\end{tabular}

Sumber : Hasil Pengelolaan Data menggunakan Excel. 
Tingkat Utang Optimal dan Speed of Adjustment. Berikut hasil peregresian dengan metode Generalized Moment Method (GMM) setelah hasil perhitungan model tingkat optimal atau optimal leverage dan speed of adjustment :

Tabel 7. Hasil Metode Generalized Moment Method (GMM)

\begin{tabular}{crrrr}
\hline \hline Variable & Coefficient & Std. Error & t-Statistic & Prob. \\
\hline \hline OPT & -0.578121 & 0.072203 & -8.006903 & 0.0000 \\
SPEED & 0.663239 & 0.044643 & 14.85666 & 0.0000 \\
\hline \hline
\end{tabular}

Sumber : Hasil Pengelolaan Data metode Generalized Moment Method (GMM) menggunakan Eviews 6.

\section{Uji Hipotesis 8 :Optimal leverage mempengaruhi capital structure}

Dari Tabel 4.6.4 menunjukkan bahwa tingkat utang optimal signifikan mempengaruhi capital structure pendekatan dinamis dengan nilai kritis 0.0000 .

\section{Hipotesis 9 :Speed of Adjustment mempengaruhi capital structure}

Tabel 4.6.4 menunjukkan bahwa speed of adjustment signifikan mempengaruhi capital structure pendekatan dinamis dengan nilai kritis 0.0000 .

\section{Nilai $\mathbf{R}^{2}$ (Koefisien Determinasi)}

Tabel 8. Koefisien Determinasi $\left(\mathrm{R}^{2}\right)$

\begin{tabular}{|l|l|}
\hline & Adjusted $\mathrm{R}^{2}$ \\
\hline Periode 2008-2012 & 0.541664 \\
\hline
\end{tabular}

Sumber : Hasil Pengelolaan Eviews 6 Tabel 4.3.

Persamaan regresi liner ganda memiliki koefisien determinasi sebesar $54.17 \%$ yang artinya sebesar $54.17 \%$ variabel dependen (capital structure) dapat dijelaskan oleh variabel independen, yaitu profitability (return on asset), firm size (ln asset), equity cost (CAPM), debt cost (interest expense after tax to total debt) dan volatility firm value (standart deviation of daily stock return) sedangkan sisanya sebesar $45.83 \%$ dapat dijelaskna oleh faktor-faktor lainnya, antara lain market-to-book ratio, long term debt, retained earning, operating risk, tangible assets, liqudity, dan lain-lain.

Pembahasan. Hasil penelitian ini secara simultan atau bersama-sama variabel asset growth, profitability (return on assets), firm size, equity cost, debt cost dan volatility firm value mempengaruhi capital structure. asset growth, profitability (return on assets), firm size, equity cost, debt cost dan volatility firm value mampu menjelaskan secara bersama-sama mempengaruhi capital structure pada perusahaan industri otomotif dan komponennyayang terdaftar di Bursa Efek Indonesia (BEI) pada tahun 2008-2012.

Profitability dalam hasil penelitian ini menunjukkan memiliki pengaruh negatif terhadap capital structure. Menurut Manurung (2012) profitability dengan pengukuran return on asset tidak mempengaruhi capital structure secara signifikan. Menurut Titman dan Wessels (1988) bahwa profitability mempengaruhi capital structure secara signifikan negatif . Hal ini konsisten dengan penelitian Titman dan Wessels (1988) bahwa profitability mempengaruhi capital structure secara signifikan negatif karena profitabilitas masa lalu dan jumlah laba yang ditahan menjadi hal penting dalam menentukan struktur pendanaan. Apabila perusahaan yang mampu menghasilkan profitabilitas yang lebih tinggi atau lebih menguntungkan bearti perusahaan mempunyai akses 
yang lebih besar dalam pendanaan internalnya dan cenderung menggunakan sedikit sumber dana eksternal (utang dan ekuitas) dalam struktur pendanaannya.

Hal ini terjadi karena industri otomotif dan komponen yang terdaftar di Bursa Efek Indonesia mampu meningkatkan kinerjanya dan melakukan investasi dengan baik sehingga profit yang dihasilkan cukup untuk memenuhi kebutuhan investasiperusahaanya dan cenderung lebih sedikit menggunakan pendanaan eksternal. Konsisten dengan teori pecking order yang menyatakan bahwa perusahaan dalam memenuhi kebutuhan pendanaan aset akan menggunakan sumber dana internalnya terlebih dahulu yaitu dari hasil kegiatan operasi perusahaan, laba yang ditahan dan lain-lainnya, baru kemudian sumber dana eksternal seperti pinjaman (utang) dan modal sendiri (ekuitas). Profitability merupakan faktor yang menyebabkan keputusan sumber pendanaan perusahaan (capital structure).

Hasil penelitian ini menujukkan firm size berpengaruh signifikan negatif terhadap capital structure. Menurut Titman dan Wessels (1988) firm size mempengaruhi capital structure secara signifikan negatif. Menurut Deari dan Deari (2009) menyatakan bahwa perusahaan unlisted di Macedonia menggunakan utang lebih banyak dibandingkan dengan perusahaan listed. Firm size tidak memiliki pengaruh terhadap keputusan capital structure pada perusahaan listed maupun unlisted di Macedonia. Hal ini konsisten dengan penelitian Titman dan Wessels (1988) bahwa firm size mempengaruhi capital structure secara signifikan negatif karena ukuran perusahaan juga menentukan sumber pendanaan yang dibutuhkan perusahaan. Kecil kemungkinan perusahaan yang berukuran besar mengalami kebangkrutan karena perusahaan berukuran besar lebih mudah dalam hal pendanaanya.

Hal ini terjadi karena industri otomotif dan komponen yang terdaftar di Bursa Efek Indonesia merupakan perusahaan yang berukuran besar sehingga dalam pendanaan untuk kebutuhan asetnya lebih mudah dan cenderung pendanaannya berasal dari internal perusahaan dan apabila sumber internal tidak cukup memenuhi kebutuhan maka salah satu pemenuhan dana yang pendanaan berasal dari eksternal perusahaan (utang dan ekuitas) hal ini sesuai atau konsisten dengan teori pecking order.

Berdasarkan hasil penelitian ini equity costtidakmempengaruhi capital structure secara signifikan. Hal ini konsisten dengan penelitian Nishioka dan Baba (2004) yang menjelaskan bahwa equity cost mempengaruhi signifikan positif terhadap capital structure karena semakin tinggi return yang diharapkan perusahaan, akan semakin banyak perusahaan mencari pendanaan untuk memenuhi kepentingan si pemegang saham tersebut.

Hal ini menunjukkan bahwa equity cost tidak menjadi pertimbangan dalam keputusan pendanaan perusahaan industri otomotif dan komponen yang terdaftar di Bursa Efek Indonesia karena efek delusi dari pembiayaan ekuitas (equity cost) memerlukan proses yang panjang dan biaya yang mahal untuk menerbitkan saham baru dibanding dengan debt cost sehingga perusahaan lebih memilih menggunakan utang untuk pendanaan kebutuhan perusahaan dibanding dengan ekuitas yang harus membayar dividen selama perusahaan itu diharapkan going concern. Hal ini konsisten dengan teori pecking order yang menyatakan bahwa perusahaanakan lebih memilih menggunakan pendanaan internal terlebih dahulu, kemudian utang dan terakhir menggunakan ekuitas.

Hasil dari penelitian ini debt cost tidak memiliki pengaruh signifikan negatif terhadap capital structure. Hasil penelitian ini konsisten dengan penelitian Nishioka dan Baba (2004) yang menjelaskan bahwa terdapat pengaruh antara debt cost terhadap capital structure secara signifikan, namun tidak konsisten dengan teori trade-off.

Hal ini terjadi karena industri otomotif dan komponennya tidak mempertimbangkan pendanaan dengan utang dalam melakukan pemenuhan kebutuhannya. Perusahaan melihat tingkat bunga yang terus meningkat maka perusahaan akan lebih memilih menggunakan pendanaan internalnya saja dan ekuitas untuk pemenuhan kebutuhan aset perusahaan sehingga keputusan pendanaan menggunakan utang akan menurun dan bahkan tidak menjadi pertimbangan keputusan pendanaan perusahaan. Oleh karena itu hasil penelitian ini menunjukkan debt cost tidak memiliki pengaruh signifikan negatif terhadap capital structure dan konsisten dengan teori pecking order. 
Volatility firm value tidak mempengaruhi capital structuresecara signifikan. Hal ini tidak konsisten dengan penelitian Nishioka dan Baba (2004) bahwa volatility firm value mempengaruhi capital structure secara signifikan dengan teori trade-off sebagai kerangka dasarnya.

Hal ini terjadi karena saham yang dimiliki sebagian perusahaan industri otomotif dan komponennya yang terdaftar di Bursa Efek Indonesia tidak likuid yang artinya jarang terjadi trading sehingga hal ini tidak dapat dijadikan sebagai patokan untuk keputusan pendanaan. Hal ini tidak sesuai dengan teori market timing yang menyatakan bahwa perusahaan akan menerbitkan ekuitas pada saat market value tinggi dan menerbitkan kembali pada saat market value rendah. Oleh karen itu volatility firm value tidak berpengaruh signifikan terhadap keputusan capital structure.

Dengan metode Generalized Moment Method (GMM) tingkat utang optimal dan speed of adjustment memilki pengaruh yang signifikan. Hasil penelitian ini konsisten dengan penelitian Loof (2003) bahwa dalam capital structure pendekatan dinamis terdapat pencapaian target optimal leverage dan speed adjustment.

Hal ini bearti bahwa pada perusahaan industri otomotif dan komponennya yang terdaftar di Bursa Efek Indonesia terjadipenyesuaian menuju tingkat utang optimal (speed adjustment)yang lambat karena adanya terjadi struktur modal yang dinamis maka perusahaan akan selalu melakukan pecapaian target tingkat utang optimalnya agar tidak berlebihan yang dapat menyebabkan biaya financial distress dan juga akan melakukan penyesuaian dengan speed of adjustment tersebut dalam waktu yang cenderung lama karena tingkat utang yang terobservasi berbeda dari tingkat utang optimal (optimal leverage) akibat adanya biaya penyesuaian (adjustment cost). Perusahaan tidak dapat langsung menyesuaikan rasio utangnya ke tingkat optimal karena hal ini membutuhkan waktu dan biaya yang besar.

Hal ini konsisten dengan penelitian Fischer et al. (1989), Zwiebel (1996), dll. dalam Manansang (2012) bahwa tingkat utang yang terobeservasi (aktual) berbeda dengan tingkat utang optimal (target leverage) akibat adanya biaya penyesuaian (adjustment cost). Perusahaan tidak dapat langsung menyesuaikan rasio utangnya ke tingkat optimal karena hal ini membutuhkan waktu dan biaya yang besar.

\section{DAFTAR RUJUKAN}

Ajija, Shochrul R., Sari, Dyah W., dan Setianto, Rahmat H. (2011) Cara Cerdas Menguasai Eviews. Jakarta: Salemba Empat

Aritonang, Lerbin R. (2007) Riset Pemasaran: Teori dan Praktek. Bogor: Ghalia Indonesia

Brealey, Richard A., Myers, Stewart C., dan Marcus, Alan J. (2007) Dasar-dasar Manajemen Keuangan Perusahaan. Jilid 2. Edisi ke-5. Jakarta: Erlangga

Brigham, Eugene F., dan Gapenski, Louis C. (1996) Intermediate Financial Management. Edisi ke-5. Orlando: The Dryden Press

Brigham, Eugene., dan Houston, Joel F. (2001) Fundamentals of Financial Management. Edisi 9. New York: Harcourt College Publishers

Brooks, R. (2013) Financial Management.Edisi ke-2. Harlow: Pearson Education

Deari, Fitim dan Deari, Media. (2009) The Determinants of Capital Structure: Evidence from Macedonian Listed and Unlisted Companies. Stiinne Economice. 56: 91-102

Fama, Eugene F., dan French, Kenneth R. (2000) Testing Trade-Off and Pecking Order Predictions about Dividends and Debt. The Review of Financial Studies, 15( 1): 1-33

Fan, Joseph. P.H, Titman, Sheridan., dan Twite, Garry. (2011) An International Comparison of Capital Structure and Debt Maturity Choices. AFA 2005 Philadelphia Meetings 
Gaud, Philippe., Jani, Elion., Hoesli, Martin., dan Bender, Andre. (2003) The capital structure of Swiss : An empirical analysis. The International Center for Financial Asset Management and Engineering (FAME)

Gitman, Lawrence J., dan Zutter, Chad J. (2012) Principles of Managerial Finance.Edisi ke-13. Harlow, Essex: Pearson Education Limited

Hesmati, Almas. (2001) The Dynamic of Capital Structure: Evidence From Swedish Micro and Small Firm. Research in Banking and Finance. Volume 2:199-24

Ismiyanti, Fitri., dan Armansyah, Rohmad F. (2010) Motif Go Public, Herding, Ukuran Perusahaan dan Underpricing pada Pasar Modal Indonesia. Jurnal Manajemen Teori dan Terapan Tahun ke 3 No 1

Korteweg, Arthur., dan Strebulaev, Ilya A. (2012) An Empirical Model of Dynamic Capital Structure. Seminar at Arizona State University

Loof, Hans. (2003) Dynamic Optimal Capital Structure and Technological Change. Discussion Paper Centre for European Economic ResearchNo 03-06

Manansang, Rizal E. (2012) Analisis Pengaruh Karakteristik Kepemilikan Terhadap Tingkat Utang Perusahaan Dengan Pendekatan Dinamis.Disertasi Doktor Program Pascasarjana Ilmu Manajemen Falkutas Ekonomi Universitas Indonesia. Depok

Manurung, Adler H. (2011) Determinan Struktur Kapital Perusahaan di Indonesia. Jurnal Akutansi-FE Untar. Volume XV

\section{Press}

Margaretha, Farah. (2007) Manajemen Keuangan Bagi Industry Jasa. Jakarta: Grasindo

Margaretha, Farah., dan Ramadhan, Rizky A. (2010). Faktor-Faktor yang Mempengaruhi Struktur Modal pada Industri Manufaktur di Bursa Efek Indonesia. Jurnal Bisnis dan Akutansi, 12 (2): 119-130

Nishioka, Shinichi., dan Baba, Naohiko. (2004) Dynamic Capital Structure of Japanese Firms : How Far Has the Reduction of Excess Leverage. Bank of Japan Working Paper Series No 4. Edisi 16

Prihadi, Toto. (2013) Analisis Laporan Keuangan Lanjutan : Proyeksi dan Valuasi. Jakarta: PPM

Rajan, Raghuram G., dan Zingales, Luigi. (1995) What Do We Know about Capital Structure? Some Evidence from International Data. The Journal of Finance, 50(5): $1421-1460$

Ruslim, Herman. (2010) Pengaruh Karakteristik Perusahaan Terhadap Struktur Modal Dinamis (Pendekatan Nilai Pasar) di Bursa Efek Indonesia. Jurnal Ekonomi. Volume $X V$, Hal 320-330

Sartono, R. Agus. (2001) Manajemen keuangan: Teori dan Aplikasi. Edisi ke-4. Yogyakarta: BPFE-Yagyakarta

Seftianne, dan Handayani, Ratih. (2011) Faktor-Faktor yang Mempengaruhi Struktur Modal Pada Perusahaan Publik Sektor Manufaktur. Jurnal Bisnis dan Akutansi. Vol 13. No. 1. Hal 39-56

Sekaran, Uma., dan Yon, Kwan Men. (2006) Metodologi Penelitian Untuk Bisnis. Jilid 2. Edisi 4. Jakarta: Salemba Empat

Sova, Maya. (2013) Pengaruh Ratio Leverage Terhadap Volatilitas Saham pada Industri Barang Konsumsi di Bursa Efek Indonesia Tahun 2004-2008. E-Journal WIDYA Ekonomika 
Sunder, Lakshmi Shyam., dan Myers, Stewart C. (1994) Testing Static Tradeoff Against Pecking Order Models of Capital Structure. Journal of Financial Economics, 51: 219-244

Titman, Sheridan., dan Wessels, Roberto. (1988) The Determinants of Capital Structure Choice. The Journal of Finance. 43 (1): 1-19 